\title{
IMPLEMENTASI INDEPENDENSI HAKIM DALAM PELAKSANAAN KEKUASAAN KEHAKIMAN
}

\author{
Andi Suherman \\ Mahasiswa Magister, Program Pascasarjana, Universitas Muslim Indonesia, Makassar \\ Email Corresponding Author: andisuherman219@gmail.com
}

Received: 31 Agustus 2019

Accepted: 27 September 2019

\begin{abstract}
Abstrak. Tujuan penulisan memberikan sumbangan pemikiran kepada publik tentang problematika independensi hakim sebagai pelaksana kekuasaan kehakiman, dan merupakan instrumentarium hukum bagi hakim dalam melaksanakan fungsinya mengadili dan memutus suatu perkara yang dihadapkan kepadanya agar terbebas dari segala interfensi dan atau pengaruh dari lingkungan kekuasaan lainnya baik itu dari lingkungan organ kekuasaan eksekutif maupun dari lingkungan organ kekuasaan legislatif. Artikel ini menggunakan tipe penelitian normatif, dan memberikan hasil penelitian ini mengemukakan bahwa hakim dalam memutus perkara di Indonesia masih eksis menggali dan menemukan rasa keadilan ditengah masyarakat, bahkan dengan pendekatan norma agama dimana diketahui masyarakat Indonesia cukup patuh terhadap norma agama.
\end{abstract}

Kata Kunci:

Independensi;

Hakim;

Kekuasaan;

Kehakiman.

artikel dengan akses terbuka dibawah lisensi CC BY -4.0

\section{PENDAHULUAN}

\section{A. Latar Belakang}

Shetreet S, \& J. Deschnes, mengatakan bahwa kemerdekaan kekuasaan kehakiman (selanjutnya disebut dengan istilah independensi), sudah sejak lama dipandang perlu dalam sistem peradilan, tetapi konsep tersebut tidak memperoleh perhatian yang cukup berarti dalam praktiknya. Namun demikian, independensi kekuasaan kehakiman sebagai suatu konsep telah mendapat perhatian penuh dan menjadi bahan kajian. ${ }^{1}$

Independensi Hakim telah menjadi perdebatan panjang dalam sejarah ketatanegaraan semenjak lahirnya ide atau gagasan bernegara hukum. Pro kontra tentang perlunya kebebasan diberikan kepada Hakim lahir dari kalangan pragmatisme berhadapan dengan aliran progresif.

Penganut aliran pragmatisme sebagai pendukung paham positivistik menghendaki Hakim adalah ibarat trompet/corong undang-undang (Bouche De Laloi), sementara pengikut aliran progresif menghendaki kebebasan hakim yang bukan sekedar

${ }^{1}$ Ahmad Kamil. (2012). Filsafat Kebebasan Hakim. Jakarta: Kencana Prenada Media Group, hlm. 207. 
penerap undang-undang, melainkan adalah penemu dan pembentuk hukum (Rechtsvinding and Rechtsvorming).

Semangat pragmatisme positivistik yang lahir dari suasana bernegara dan berpemerintahan dengan paham feodalisme, dimana hakim-hakim yang diangkat oleh Raja di kala zaman itu, adalah Hakim-Hakim feodal yang wajib menerapkan undang-undang bentukan feodal, tiada pilihan lain bagi Hakim selain tunduk pada perintah kekuasaan feodal.

Namun demikian pendukung paham progresif selalu menyuarakan dan memperjuangkan agar Hakim selaku pelaksana kekuasaan kehakiman melalui peradilan-peradilan negara, harus independent, mandiri dalam melaksanakan fungsi yudisialnya demi tegaknya hukum yang berkeadilan sesuai dengan nilainilai kebajikan.

Hakim bukanlah sekedar penerap hukum melalui metode silogisme semata (trompet/corong undang-undang), melainkan Hakim adalah penerap, penemu (judge lawfinding) dan dapat membentuk hukum (judge made law) yang adil dan bijaksana. Oleh karena itu, Hakim tidak boleh terikat hanya pada hukum dalam arti peraturan perundang-undangan yang sarat dengan dominasi kepentingankepentingan minoritas yang kuat (the ruler).

Hakim harus diberi kebebasan dalam melaksanakan fungsi yudisialnya, agar setiap perkara yang dihadapkan padanya benar-benar dapat diputus sesuai dalam memeriksa, mengadili dan memutus perkara yang dihadapkan kepadanya, benarbenar diputusnya dengan adil dan bijaksana.

Untuk mewujudkan kebebasan Hakim tersebut, maka harus ada jaminan hukum, agar Hakim dapat terbebas dari segala bentuk interfensi dari kekuasaan negara dan pemerintahan, terbebas dari segala bentuk intimidasi dari kekuatan-kekuatan pemaksa lainnya, dan terbebas dari ancaman-ancaman yang dapat mempengaruhi beban psikologis dan psikisnya baik sewaktu sedang mengadili maupun setelah dijatuhkannya putusan.

Adanya jaminan hukum bagi Hakim dalam melaksanakan fungsi peradilannya, maka Hakim diharapkan dapat menjadi penerap hukum yang baik oleh karena ia merupakan interpreter hukum yang handal/piawai menginterpretasi hukum dan bijaksana dalam menilai serta menerapkan keadilan.

\section{B. Permasalahan}

Agar jelas arah dari pemaparan tulisan ini, maka dirumuskan permasalahan sebagai berikut:

1. Bagaimanakah Negara memberi jaminan bagi Hakim dalam melaksanakan fungsi kekuasaan kehakiman secara independen?

2. Apakah landasan teoritiknya bagi Hakim dalam melaksanakan fungsi kekuasaan kehakiman secara independen?

\section{METODE}

Artikel ini menggunakan tipe penelitian normatif. Bahan primer dan sekunder bersumber dari bacaan penulis diperpustakaan hukum menjadi rujukan dalam menyelesaikan penelitian ini. Bahan-bahan hukum yang terangkum lalu diolah dengan mendeskripsikan secara kualitatif, dengan pendekatan preskriptif. 


\section{PEMBAHASAN}

\section{A. Sistem Kekuasaan Kehakiman}

Sistem kekuasaan kehakiman suatu negara tidak terlepas dari sistem hukum yang dianut atau diberlakukannya. Bagi negara yang menganut sistem hukum Eropa Kontinental (Civil Law System) rujukan hukum utamanya adalah kodifikasi (Hukum Tertulis) Peraturan Perundang-Undangan yang telah ditetapkan disyahkan oleh negara melalui badan atau lembaga negara yang diberi wewenang untuk itu. Di Indonesia badan atau lembaga negara yang diberi wewenang demikian itu, adalah Dewan Perwakilan Rakyat dan Presiden.

Bagi negara yang menganut sistem hukum Common Law rujukan hukumnya yang utama adalah hukum kebiasaan (Common) atau juga dalam tradisi akademik biasa disebut dan dilembagakan sebagai Jurisprudensi, menjadikan putusan-putusan Hakim sebagai preseden rujukan hukum bagi Hakim lainnya dalam memutus suatu perkara. Secara teori, dikatakan bahwa pusat kegiatan hukum bagi negara penganut sistem ini adalah di peradilan-peradilan. Artinya Hakim mempunyai peranan dan fungsi yang sangat besar dalam pembentukan hukum kongkret.

Sistem-sistem hukum tersebut memberi pengaruh yang dominan terhadap sistem kekuasaan kehakiman yang berlaku. Bagi negara penganut Civil Law akan memberi pengaruh besar terhadap Hakim sebagai pelaksana kekuasaan kehakiman yang mana menganut paham kodifikasi. Artinya Hakim selalu menjadikan peraturan perundang-undangan sebagai skala prioritas dalam pelaksanaan fungsi yudisialnya.

Demikian pula halnya terhadap negara penganut sistem Common Law, akan memberi pengaruh terhadap independensi Hakim sebagai pelaksana kekuasaan kehakiman yang selalu berkiblat pada hukum Common (kebiasaan umum) yang terjelma melalui jurisprudensi hakim-hakim dalam putusan peradilan.

Dalam perkembangannya, berdasarkan dari hasil-hasil penelitian yang telah dilakukan oleh ahli-ahli hukum kedua sistem hukum dimaksud tersebut telah saling pengaruh mempengaruhi dalam pelaksanaannya, sehingga tidak ditemukan lagi secara ketat pembeda dari kedua sistem hukum tersebut dalam prakteknya, maka pula turut berpengaruh terhadap independensi Hakim sebagai pelaksana kekuasaan kehakiman.

Artinya sistem kekuasaan kehakiman di negara-negara penganut Civil Law, tidak lagi semata terbelenggu dengan sistem kodifikasi (Hukum Tertulis), melainkan terbuka ruang untuk merujuk pada hukum yang tidak tertulis .Sebaliknya pada sistem Common Law Juga membuka diri untuk bergeser dari prinsip preseden.

Pergeseran paradigma sistem hukum tersebut, membuka ruang luas bagi Hakim dalam melaksanakan fungsi kekuasaan kehakiman secara independen dari aspek rujukan hukum yang dapat dijadikan pedoman dalam memutus suatu perkara yang dihadapkan kepadanya untuk penyelesaian dengan adil dan bijaksana.

\section{B. Independensi Hakim sebagai Pelaksana Kekuasaan Kehakiman di Indonesia}

Kekuasaan kehakiman (Judicial Power) menurut sistem ketatanegaraan Indonesia adalah kekuasaan yang merdeka yang dilakukan oleh sebuah Mahkamah Agung dan badan peradilan yang berada di bawahnya, dan oleh sebuah Mahkamah Konstitusi, untuk menyelenggarakan peradilan guna menegakkan hukum dan keadilan. 
Kekuasaan kehakiman yang merdeka dalam arti independen tersebut, telah ditegaskan pada Pasal 24 ayat (1), ayat (2) dan ayat (3) Undang-Undang Dasar Negara Republik Indonesia Tahun 1945, sebagai berikut:

(1) Kekuasaan kehakiman merupakan kekuasaan yang merdeka untuk menyelenggarakan peradilan guna menegakkan hukum dan keadilan.

(2) Kekuasaan kehakiman dilakukan oleh sebuah Mahkamah Agung dan badan peradilan yang berada dibawahnya dalam lingkungan peradilan umum, lingkungan peradilan agama, lingkungan peradilan Militer, lingkungan peradilan tata usaha negara, dan oleh sebuah Mahkamah Konstitusi.

(3) Badan-badan lain yang fungsinya berkaitan dengan kekuasaan kehakiman diatur dalam undang-undang.

Apabila dikaji lebih jauh tentang kekuasaan kehakiman yang merdeka dalam arti independen, terbebas dari interfensi pengaruh kekuasaan lainnya, maka penegasan Hukum Dasar Negara tersebut, lebih lanjut dikembangkan di dalam Undang-Undang Nomor 48 Tahun 2009 tentang Kekuasaan Kehakiman, demikian juga dalam Undang-Undang Nomor 14 Tahun 1985 tentang Mahkamah Agung yang telah dirubah dengan UU. No. 5 Tahun 2004 tentang Perubahan atas UU. No. 14 Tahun 1985 juncto Undang-Undang No. 3 Tahun 2009 tentang Perubahan Kedua UU. No. 14 Tahun 1985 tentang Mahkamah Agung.

Pada Pasal 1 Butir 1 UU No. 48 Tahun 2009 tentang Kekuasaan Kehakiman ditegaskan:

Kekuasaan kehakiman adalah kekuasaan negara yang merdeka untuk menyelenggarakan peradilan guna menegakkan hukum dan keadilan berdasarkan Pancasila dan Undang-Undang Dasar Negara Republik Indonesia Tahun 1945, demi terselenggaranya Negara hukum Republik Indonesia.

Pada Penjelasan Resmi Angka I UU No. 48 Tahun 2009 memuat klarifikasi yang lebih tegas tentang adanya independensi badan-badan peradilan dalam penyelenggaraan peradilan. Hemat penulis perihal tersebut adalah:

"UUD NRI Tahun 1945 menegaskan Indonesia adalah negara hukum. Sejalan dengan ketentuan tersebut maka salah satu prinsip penting negara hukum adalah adanya jaminan penyelenggaraan kekuasaan kehakiman yang merdeka, bebas dari pengaruh kekuasaan lainnya untuk menyelenggarakan peradilan guna menegakkan hukum dan keadilan."

Senada dengan irama pemahaman di atas, dipertegas pula pada Pasal 3 ayat (1) dan (2) UU. No. 48 Tahun 2009, sebagai berikut :

(1) Dalam menjalankan tugas dan fungsinya, hakim dan hakim konstitusi wajib menjaga kemandirian peradilan.

(2) Segala campur tangan dalam urusan peradilan oleh pihak lain di luar kekuasaan kehakiman dilarang, kecuali dalam hal-hal sebagaimana dimaksud dalam Undang-Undang Dasar Negara Republik Indonesia Tahun 1945.

Penegasan kemandirian kekuasaan kehakiman tersebut di atas, secara struktural dan vertikal berpuncak pada Mahkamah Agung. Hal itu diatur dalam pasal 2 UU No. 14 Tahun 1985 (Perubahannya dengan UU No. 5 Tahun 2004 Junto UU. No. 3 Tahun 2009), bahwa: Mahkamah Agung adalah Pengadilan Negara Tertinggi dari semua lingkungan peradilan, yang dalam melaksanakan tugasnya terlepas dari pengaruh pemerintah dan pengaruh-pengaruh lainnya. 
Independensi kekuasaan kehakiman yang dijamin oleh hukum dasar negara dan peraturan perundang-undangan di bawahnya sebagai peraturan pelaksanaan operasional, melekat dilaksanakan oleh hakim-hakim Pengadilan dari badan peradilan di semua lingkungan peradilan dalam melaksanakan fungsi kekuasaan di bidang kehakiman.

Independensi kekuasaan kehakiman bukan hanya ditujukan terhadap struktur kelembagaan peradilan, melainkan juga terhadap hakim-hakim peradilan dalam melaksanakan fungsinya dalam mengadili dan memutus suatu perkara yang dihadapkan kepadanya.

Jimly Asshiddiqie, mengatakan bahwa kata merdeka dan terlepas dari pengaruh kekuasaan pemerintah, terkandung pengertian yang bersifat fungsional dan sekaligus institusional. ${ }^{2}$

Penyelenggaraan kekuasaan kehakiman diserahkan kepada badan-badan peradilan yang ditetapkan dengan undang-undang dengan tugas pokok untuk menerima, memeriksa, mengadili dan menyelesaikan setiap perkara yang diajukan kepadanya.

Sejalan dengan tugas pokok tersebut, maka pengadilan tidak boleh menolak untuk memeriksa dan mengadili suatu perkara yang diajukan oleh yustisiabel dengan dalih bahwa hukumnya tidak ada atau kurang jelas. Hal ini berarti pengadilan wajib untuk memeriksa, mengadili dan memutus suatu perkara yang diajukan oleh pencari keadilan.

Pada Pasal 10 ayat (1) UU. No. 48 Tahun 2009, menegaskan bahwa:

Pengadilan dilarang menolak untuk memeriksa, mengadili, dan memutus suatu perkara yang diajukan dengan dalih bahwa hukum tidak ada atau kurang jelas, melainkan wajib untuk memeriksa dan mengadilinya.

Implementasi dari tugas dan fungsi kekuasaan kehakiman yang dijalankan oleh hakim-hakim dari lingkungan peradilan, diharapkan dapat menegakkan hukum dan keadilan secara merdeka, independen, tanpa adanya interfensi, dari lingkungan kekuasaan lainnya dan pengaruh dari unsur lain diluar kepentingan hukum dan keadilan.

Atas dasar itu, maka hakim dituntut agar senantiasa melakukan penggalian, mengikuti dinamika sosial, dan memahami nilai-nilai hukum dan rasa keadilan yang hidup dalam masyarakat. Keharusan bagi hakim tersebut, dipertegas pada Pasal 5 UU. No. 48 Tahun 2009, bahwa:

(1) Hakim dan hakim konstitusi wajib menggali, mengikuti, dan memahami nilainilai hukum dan rasa keadilan yang hidup dalam masyarakat.

(2) Hakim dan hakim konstitusi harus memiliki integritas dan kepribadian yang tidak tercela, jujur, adil, profesional, dan berpengalaman di bidang hukum.

(3) Hakim dan hakim konstitusi wajib menaati Kode Etik dan Pedoman Perilaku hakim.

Tuntutan bagi hakim tersebut, tidak lain adalah merupakan konsekuensi hukum dan profesionalitas hakim dalam menjalankan fungsi kekuasaan kehakiman yang merdeka untuk menegakkan hukum dan keadilan melalui badan-badan peradilan.

Adanya independensi hakim dalam menjalankan fungsi kekuasaan kehakiman melalui badan-badan peradilan negara, dimaksudkan agar hakim benar-benar

${ }^{2}$ A. Ahsin Thohari. (2004). Komisi Yudisial dan Reformasi Peradilan. Jakarta: ELSAM, hlm. 1. 
dapat mandiri, bebas dan merdeka dari segala sesuatu campur tangan yang dapat mempengaruhi fungsinya dalam memeriksa, mengadili dan memutus suatu perkara yang dihadapkan kepadanya.

Dengan demikian, secara normatif (yuridis-formal), negara melalui konstitusi dan peraturan perundang-undangan di bawahnya, telah memberi jaminan tentang independensi Hakim dalam melaksanakan fungsi yudisialnya demi penegakan hukum dan keadilan.

\section{Landasan Teoritik Independensi Hakim}

Untuk menemukan kerangka dasar atau landasan teoritis tentang lahirnya independensi Hakim dalam melaksanakan fungsi yudisialnya di lingkunganlingkungan peradilan negara sebagai pelaksana kekuasaan kehakiman, maka harus dirujuk pada teori dan atau konsep-konsep pembagian dan pemisahan kekuasaan.

Teori tentang kekuasaan kehakiman, jika dirujuk dari latar belakang sejarahnya, adalah merupakan derivasi atau turunan dari teori pembagian kekuasaan dan pemisahan kekuasaan (Division or Separation of Power) sebagaimana diajarkan oleh John Locke dan Montesquieu.

John Locke dalam karyanya yang berjudul "Two Treaties of Government", mengajarkan agar kekuasaan di dalam suatu negara didistribusi atau dibagi-bagi kedalam beberapa organ-organ badan kenegaraan yang berbeda. ${ }^{3}$

Untuk memproteksi adanya penumpukan kekuasaan menurut John Locke hanya pada organ-organ kenegaraan tertentu, maka diperlukan pendistribusian kekuasaan kepada beberapa organ kenegaraan, agar terhindar dari penyalahgunaan kekuasaan yang hanya jika terpusat pada satu organ saja.

John Locke membagi kekuasaan ke dalam beberapa pembagian sebagai berikut:

1. Kekuasaan Legislatif (Legislative Power)

2. Kekuasaan Eksekutif (Executive Power)

3. Kekuasaan Federatif (Federative Power).

Distribusi kekuasaan kepada tiga organ badan kekuasaan kenegaraan tersebut, dimana kekuasaan yudikatif (Judicative Power) dimasukkan ke dalam bagian organ kekuasaan eksekutif, dengan alasan bahwa kekuasaan eksekutif sebagai kekuasaan melaksanakan undang-undang mencakup pula di dalamnya kekuasaan mengadili sebagai pelaksanaan undang-undang.

Lebih lanjut, La Ode Husen, menilai bahwa pemikiran John Locke tentang distribusi kekuasaan muncul sebagai reaksi terhadap absolutisme raja, dimana pada abad 14-15 kekuasaan pemerintahan di Eropa Barat terpusat hanya pada satu tangan yaitu raja. Baru memasuki abad ke 17 muncullah konsep dan gagasan untuk mengambil alih kekuasaan membentuk perundang-undangan dari tangan raja, yang diserahkan kepada suatu badan kenegaraan (Staatkundig orgaan) yang berdiri sendiri. Sebelumnya, akhir abad pertengahan, yang mula-mula diambil dari tangan raja adalah kekuasaan kehakiman, yang kemudian diikuti dengan penyerahan kepada badan peradilan. ${ }^{4}$

${ }^{3}$ Bambang Sutiyoso \& Sri Hastuti Puspitasari. (2005). Aspek-Aspek Perkembangan Kekuasaan Kehakiman di Indonesia. Yogyakarta: UII Press, hlm. 18.

${ }^{4}$ La Ode Husen. (2009). Negara Hukum, Demokrasi dan Pemisahan Kekuasaan. Makassar: PT. Umitoha Ukhuwah Grafika, hlm. 40. 
Munculnya atau hadirnya kekuasaan kehakiman sebagai bagian dari cabang kekuasaan eksekutif menurut teori John Locke, dilatarbelakangi oleh kekuasaan raja yang absolut. Oleh karena itu, wajar bila semula kekuasaan kehakiman berada sebagai bagian dari kekuasaan eksekutif (Executive Power) yang berada di tangan raja, dicabut dan diambil alih dan diserahkan kepada organ kenegaraan baru yaitu badan peradilan sebagai pelaksana kekuasaan kehakiman.

Dari aspek pendekatan teoritis, maka kekuasaan raja yang mula-mula dicabut dari tangannya adalah kekuasaan kehakiman yang fungsinya dijalankan oleh badanbadan peradilan. Barulah kemudiannya, menyusul pencabutan kekuasaan di bidang pembentukan peraturan perundang-undangan (legislatif).

Pencabutan kekuasaan kehakiman dari tangan raja yang absolut, seirama kemudian dengan munculnya pemikiran dari Baron de Montesquieu yang dituangkannya dalam buku yang berjudul "L'spirit des Lois", dimana Montesquieu menawarkan konsep yang berbeda dengan konsep yang telah ditawarkan oleh John Locke.

Menurut Montesquieu, untuk tegaknya negara hukum demokrasi perlu diadakan pemisahan kekuasaan negara ke dalam tiga poros kekuasaan sebagai berikut :

1. Kekuasaan Legislatif (Legislation of Power)

2. Kekuasaan Eksekutif (Executive of Power)

3. Kekuasaan Yudikatif (Judicative of Power).

Kekuasaan legislatif, di dalamnya tercakup kekuasaan dalam pembentukan peraturan perundang-undangan. Kekuasaan eksekutif, melingkupi kekuasaan di bidang pelaksanaan undang-undang. Kekuasaan kehakiman (yudikatif), mencakup kekuasaan di bidang kehakiman dan peradilan dalam rangka menegakkan peraturan perundang-undangan/penegakan hukum (Law Enforcement).

Pemisahan tiga domain wilayah kekuasaan kenegaraan tersebut, diistilahkannya dengan tiga poros kekuasaan, yang masing-masing antar satu dengan lainnya terpisah, baik mengenai subjeknya maupun mengenai fungsinya.

Gagasan tentang tiga poros sentralisasi atau pusat kekuasaan kenegaraan yang terpisah tersebut, kemudian oleh murid Montesquieu yaitu Immanuel Kant disebutnya dengan nama Trias Politica, sebagai rangkaian atau untaian kata dari : Tri, artinya tiga, as, artinya pusat/poros, dan Politica, artinya kekuasaan.

Jika dikaji lebih mendalam secara cermat dari teori pembagian kekuasaan yang diajarkan oleh John Locke (Distribution of Power) dengan teori pemisahan kekuasaan (Separation of Power) yang diajarkan oleh Montesquieu, kemudian dikembangkan oleh muridnya Immanuel Kant dengan istilah Trias Politica, maka pada teori Trias Politica lah kekuasaan kehakiman dan peradilan menemukan bentuknya atau yang menjadi tumpuannya.

Artinya, kekuasaan kehakiman yang fungsinya dijalankan oleh Hakim-Hakim dari berbagai lingkungan badan-badan peradilan negara sebagai organ pelaksana di bidang kekuasaan kehakiman yang independen, bebas dari segala infiltrasi, interfensi dan campur tangan dari lingkungan kekuasaan lainnya, secara teori mendapatkan justifikasi dan validitasnya dengan teori pemisahan kekuasaan Trias Politica dari Montesquieu dan Immanuel Kant.

Dalam perkembangannya, ternyata teori Trias Politica, tidak sepenuhnya dapat diterima dalam praktek ketatanegaraan. Teori ini sukar untuk diterapkan secara utuh, oleh karena dalam perkembangan bernegara adakalanya satu organ 
kekuasaan kenegaraan diserahi lebih dari pada hanya satu fungsi kekuasaan, melainkan satu organ atau badan kekuasaan kenegaraan dapat diserahi lebih dari satu fungsi kekuasaan, sebagaimana halnya kekuasaan eksekutif juga diberi fungsi di bidang kekuasaan membentuk peraturan perundang-undangan.

Amerika Serikat yang dianggap kampiun dalam menjalankan konsep pemisahan kekuasaan negara, ternyata dalam praktik ketatanegaraannya dikenal sistem saling kontrol dan saling mengadakan pertimbangan (Check and Balance System) antara kekuasaan-kekuasaan negara tersebut. Adanya hak Veto Presiden di Amerika dari rancangan undang-undang yang diajukan oleh Kongres Amerika pada hakikatnya sudah mengurangi pelaksanaan teori Trias Politica, oleh karena wewenang menetapkan undang-undang oleh legislatif (Kongres) sudah dikurangi. ${ }^{5}$

Ronald S. Lumbuun, dalam kaitan tersebut, mengatakan bahwa salah satu ciri dan persyaratan utama dari suatu negara hukum, adalah terdapatnya asas pemisahan kekuasaan (Separation of Power) atau pembagian kekuasaan (Distribution of Power) yang biasanya terdiri dari kekuasaan legislatif dalam membentuk undangundang, kekuasaan eksekutif untuk menjalankan pemerintahan berdasarkan undang-undang yang dibuat oleh lembaga legislatif tersebut, dan kekuasaan yudikatif yang menjalankan lembaga peradilan apabila terdapat penyimpangan di dalam pelaksanaan undang-undang serta kekuasaan administratif. ${ }^{6}$

Mengapa kekuasaan kehakiman yang secara fungsional diemban oleh hakimhakim peradilan diperlukan kemandirian, independensi, terbebas dari segala interfensi dan pengaruh kekuasaan lainnya?, oleh karena organ atau badan kekuasaan kenegaraan ini mengembang misi sebagai Pengadilan Negara yang hendak mewujudkan penegakan hukum dan keadilan bersendikan Ketuhanan Yang Maha Esa.

Zubaedi mengatakan bahwa sekalipun suatu negara tidak menjalankan doktrin Trias Politica, namun independensi hakim sebagai pelaksana kekuasaan kehakiman tetap juga diakui. Negara-negara. ${ }^{7}$

Dengan demikian, akar fundamental teoritis tentang adanya independensi hakim dalam melaksanakan fungsi kekuasaan kehakiman melalui peradilan negara, ditemukan dalam teori Trias Politica.

\section{KESIMPULAN DAN SARAN}

\section{A. Simpulan}

Independensi hakim sebagai pelaksana kekuasaan kehakiman menjamin bahwa Negara bagi independensi Hakim dalam melaksanakan fungsi kekuasaan kehakiman melalui peradilan-peradilan negara untuk mengadili dan memutus perkara demi hukum dan keadilan, secara normatif (yuridis-formal) telah diberikan dalam Pasal 24 ayat (1), ayat (2) dan ayat (3) Undang-Undang Dasar Negara Republik Indonesia Tahun 1945. Juga Pasal 1 Butir 1 dan Pasal 3 ayat (1) dan ayat (2) UU No. 48 Tahun 2009 tentang Kekuasaan Kehakiman. Landasan teoritis bagi Hakim

${ }^{5}$ Dahlan Thaib. (1988). Implementasi Sistem Ketatanegaraan Menurut UUD 1945. Yogyakarta: Liberty, hlm. $76-77$.

${ }^{6}$ Ronald S. Lumbuun. (2011). PERMA RI (Peraturan Mahkamah Agung Republik Indonesia): Wujud Kerancuan antara Praktik Pembagian dan Pemisahan Kekuasaan. Jakarta: PT. Raja Grafindo Persada, hlm. $2-3$.

${ }^{7}$ Zubaedi. (2007). Filsafat Barat: Dari Logika Baru Rene Descartes hingga Revolusi Sains ala Thomas Kuhn (diedit oleh Ilyya Muhsin). Yogyakarta: Ar-Ruzz Media, hlm. 43 - 44. 
dalam melaksanakan fungsi kekuasaan kehakiman secara independen melalui peradilan-peradilan negara, mendapatkan justifikasi dan validitasnya dengan teori pemisahan kekuasaan Trias Politica dari Montesquieu dan Immanuel Kant.

\section{B. Saran}

Meskipun secara konseptual telah ada jaminan independensi bagi Hakim dalam pelaksanaan fungsi kekuasaan kehakiman melalui peradilan-peradilan negara, namun perlu didukung dengan semangat bernegara hukum yang demokratis, terutama dari lingkungan badan atau organ kekuasaan negara yang lainnya.

\section{REFERENSI}

A. Ahsin Thohari. (2004). Komisi Yudisial dan Reformasi Peradilan. Jakarta: ELSAM.

Ahmad Kamil. (2012). Filsafat Kebebasan Hakim. Jakarta: Kencana Prenada Media Group.

Bambang Sutiyoso \& Sri Hastuti Puspitasari. (2005). Aspek-Aspek Perkembangan Kekuasaan Kehakiman di Indonesia. Yogyakarta: UII Press.

Dahlan Thaib. (1988). Implementasi Sistem Ketatanegaraan Menurut UUD 1945. Yogyakarta: Liberty.

H. F. Abraham Amos. (2007). Katastropi Hukum \& Quo Vadis Sistem Politik Peradilan Indonesia: Analisis Sosiologi Kritis terhadap Prosedur Penerapan dan Penegakan Hukum di Indonesia. Jakarta: PT. Raja Grafindo Persada.

Hans Kelsen. (2006). Teori Umum tentang Hukum dan Negara (Terj. oleh Raisul Muttaqien). Bandung: Nusamedia \& Nuansa.

La Ode Husen. (2009). Negara Hukum, Demokrasi dan Pemisahan Kekuasaan. Makassar: PT. Umitoha Ukhuwah Grafika.

Nurul Qamar, Muhammad Syarif, Dachran S. Busthami, Muhammad Kamal, Aan Aswari, Hardianto Djanggih, \& Farah Syah Rezah. (2017). Metode Penelitian Hukum (Legal Research Methods). Makassar: CV. Social Politic Genius (SIGn).

Nurul Qamar, Salle, Amiruddin, Kaharuddin Syah Y. Dt. Amas, Rusli Dg. Palabbi, Andi Suherman, \& Farah Syah Rezah. (2018). Negara Hukum atau Negara Kekuasaan (Rechtsstaat or Machtstaat). Makassar: CV. Social Politic Genius (SIGn).

Nurul Qamar. (2010). Negara Hukum atau Negara Undang-Undang. Makassar: Pustaka Refleksi.

Nurul Qamar. (2010). Perbandingan Sistem Hukum dan Peradilan: Civil Law System, Common Law System. Makassar: Pustaka Refleksi.

Nurul Qamar. (2011). Percikan Pemikiran tentang Hukum. Makassar: Pustaka Refleksi.

Nurul Qamar. (2012). Pengantar Politik Hukum Ketatanegaraan. Makassar: Pustaka Refleksi.

Nurul Qamar. (2014). Hak Asasi Manusia dalam Negara Hukum Demokrasi (Human Rights in Democratiche Rechsstaat). Jakarta: Sinar Grafika. 
Paul Scholten. (2005). Struktur Ilmu Hukum (Terj. oleh Bernard Arief Sidharta). Bandung: PT. Alumni.

Ronald S. Lumbuun. (2011). PERMA RI (Peraturan Mahkamah Agung Republik Indonesia): Wujud Kerancuan antara Praktik Pembagian dan Pemisahan Kekuasaan. Jakarta: PT. Raja Grafindo Persada.

Satjipto Rahardjo. (2006). Membedah Hukum Progresif. Jakarta: Kompas.

Satjipto Rahardjo. (2007). Biarkan Hukum Mengalir: Catatan Kritis tentang Pergulatan Manusia dan Hukum. Jakarta: Kompas.

Satjipto Rahardjo. (2009). Penegakan Hukum: Suatu Tinjauan Sosiologis. Yogyakarta: Genta Publishing.

Zubaedi. (2007). Filsafat Barat: Dari Logika Baru Rene Descartes hingga Revolusi Sains ala Thomas Kuhn (diedit oleh Ilyya Muhsin). Yogyakarta: Ar-Ruzz Media. 